Terbit online pada laman web jurnal: http://javit.ppj.unp.ac.id DOI: https://doi.org/10.24036/javit.v2i1

\title{
Penggunaan E-Modul di Sekolah Menengah Kejuruan Pada Mata Pelajaran Simulasi Digital
}

\author{
1, ${ }^{*}$ Sri Rahmadhani, ${ }^{2}$ Yulia Efronia, ${ }^{3}$ Elfi Tasrif \\ ${ }^{1}$ SMK Negeri 1 Sutera, ${ }^{2}$ SMK Negeri 2 Kota Sungai Penuh, ${ }^{3}$ Universitas Negeri Padang \\ *Coressponding author e-mail: rahmadhanisri4@gmail.com
}

\begin{abstract}
Abstrak
Modul berbasis elektronik atau yang sering disebut dengan e-modul adalah media pembelajaran yang menyajikan visualisasi yang dapat diakses melalui media elektronik. Sejauh ini e-modul sudah banyak dikembangkan dengan beberapa metode. Tenaga pendidik juga harus menguasai perkembangan media pembelajaran yang nantinya akan membantu proses belajar dan mengajar yang efektif dan mencapai kompetensi mata pelajaran. Simulasi digital merupakan mata pelajaran C2 atau mata pelajaran wajib di kelas X SMK. Emodul ini akan diterapkan dimata pelajaran Simulasi Digital dengan berbagai metode pengembangkan media pembelajaran. Hasil yang diperoleh antara lain yaitu tentang bagaimana keefektifan penggunaan e-modul yang diterapkan di SMK khususnya pada mata pelajaran Simulasi Digital yang dilaporkan sangat baik. Penggunaan emodul berdampak positif terhadap hasil belajar siswa dan memperoleh respon siswa yang tinggi.
\end{abstract}

Kata kunci : Media Pembelajaran, e-Modul, Tenaga Pendidik, Mata Pelajaran, Simulasi Digital.

(C) Lisensi: Creative Commons Attribution 4.0 International (CC BY 4.0) 


\section{Pendahuluan}

Media pembelajaran didunia pendidikan terkhusus dalam proses belajar dan mengajar tidak dapat dipisahkan. Media pembelejaran merupakan sebuah alat atau bahan yang dapat digunakam untuk menyampaikan apa yang diajarkan oleh guru kepada peserta didiknya. Media pembelejaran juga sering disebut dengn alat bantu bagi guru untuk melakukan proses belajar mengajar, menyamaikan materi ajar yang sudah disusun sebelumnya, dan tentunya juga untuk meningkatkan kreatifitas peserta dididk. Untuk saat ini semakin menarik media yang digunakan oleh guru maka semakin tinggi pula motivasi belajar peserta didik, hal ini dikarenakan bentuk media yang sudan bervariasi sehingga mencegah rasa bosan pada peserta didik dalam proses belajar. Pada saat sekarang inidimana perkembangan teknologi semakin pesat, sangat membantu para pendidik menjadikan media pembelajaran menjadi lebih kreatif. Memanfaatkan media merupakan suatu tugas yang diampu oleh guru sebagai tenaga pendidik atau fasilitator dalam proses belajar dan mengajar. Setiap tenaga pendidik harus mempelajari bagaimana memilih dan menetapkan media yang akan digunakan untu proses belajara dan mengajar. Seorang guru juga harus bisa memilih jeis media yang efektif untuk digunakan. Jenis media pembelajaran untuk sekarang sudah banyak sekali jenisnya dan juga sudah banyak digunakan oleh tenaga pendidik. Seiring dengan majunya teknologi, maka perkembangan media pembelajaran juga begitu cepat. Media pembelajaran bisa berbentuk multimedia, digital/elektronik dan dalam bentuk media cetak. Media yang sering digunakan untuk saat ini yaitu media berbentuk elektronik hal ini dikareakan penggunaannya yang sangat peraktis. E-modul adalah sebuah media pembelajaran yang berbasis elektronik, yang didalamnya terdiri dari teks, gambar, animasi, grafik dan video.

E-modul dapat diakses melalui media elektronik. Dengan menggunakan e-modul akan membantu siswa lebih mudah untuk memahami materi pembelajaran karena pengembangan proses pembelajaran tidak hanya membaca dengan gaya teks book, tapi juga menggunakan beberapa metode. E-modul diharapkan dapat digunakan menjadi sumber pembelajaran baru bagi siswa dan dapat meningkatkan dalam memahami konsep pembelajaran. Pembelajaran yang menggunakan emodul akan mengarahkan siswa untuk melaksanakan pembelajaran secara mandiri, karena e-modul juga dapat diartikan sebuah alat bantu dalam belajar yang dikemas dalam bentuk visualisasi. Dalam hal ini tentu saja ada beberapa komponen yang akan membantu penggunaan emodul seperti sarana prasarana alat elektronik baik itu perangkat komputer maupun handphone.

Bahan pembelajaran yang mendukung akan menciptakan pembelajaran yang bermakna. Penggunaan e-modul pada salah satu mata pelajaran di SMK yaitu mata pelajaran sistem digital banyak ditemukan bahwa penggunaan e-modul memiliki efektivitas dan meningkatkan hasil belajar pada siswa SMK. Berdasarkan penjelasan yang telah diraikan, maka dilakukan review untuk mengumpulkan data mengenai aktivitas penggunaan e-modul.

\section{Tinjauan Pustaka}

Modul sebagai sarana dan alat yang digunakan dalam pembelajaran yang berisi materi pokok, metode serta batasan-batasan dan cara mengevaluasi yang dirancang secara sistematis dan menarik untuk mencapai hasil pembelajaran yang diharapkan pada tujuan. Modul sebagai bahan pemebelajaran yang dimuat secara singkat, spesifik dan padat. Pada emodul tampilan informasi dimuat dalam e-book atau buku elektronik dengan menggunakan beberapa media bantu seperti, CD, disket, harddisk, flasdisk dan lainnya.

Pengembangan e-modul tidak terlepas dari materi-materi yang ada pada buku cetak, keberadaan e-modul mengadopsi dari buku cetak atau buku paket, perbedaan ini terlihat dari bentuk fisiknya dan cara penggunaannya. Departemen pendidikan nasional (Depdiknas, 2008) menjelaskan bahwa modul merupakan alat atau sarana pembelajaran yang berisi materi, metode, batasan-batasan dan cara mengevaluasi yang dirancang secara sistematis dan menarik untuk mencapai kompetensi yang diharapkan sesuai dengan tingkat kompleksitasnya.

Simdig atau simulasi digital merupakan salah satu bagian dari kelompok mata pelajaran produktif yang masuk pada muatan kejuruan peminatan kejuruan kelompok $\mathrm{C} 1$ pada struktur kurikulum berdasarkan bidang keahlian pada aturan (permendikbuk Nomor 70 Tahun 2013 dan SK dirjen Pendidikan Dasar dan Menengah No 330 tahun 2007). Muatan pembelajaran pada simulasi digital memuat materi yang mempelajari bagaimana komunikasi sinkron dan asinkron. 
Mata pelajaran ini diwajibkan di semua program keahlian kelas X ( Sepuluh) SMK. simulasi digital ini membekali peserta didik agar siswa dapat mengkomunikasikan gagasan atau konsep melalui media digital. Kompetensi yang diharapkan dari mata pelajaran simdig yaitu siswa menguasai keteknikan dan cara kerja yang terkait dengan mata pelajaran kejuruan. Simulasi digital meliputi pengelolaan informasi digital dan kelas maya.

Tujuan akhir dari mata pelajaran simulasi digital ini adalah agar peserta didik yang duduk di bangku sekolah menengah kejuruan dapat merealisasikan penggunaaan komputer dan perangkat-perangkat yang ada padanya serta dapat membantu mempermudah pekerjaan dalam bidang bidang kejuruan baik teknik maupun non teknik. Dengan mempelajari simulasi digital peserta didik memungkinkan dapat mengkomunikasikan pesan melalui alat-alat elektronik.

Media pembelajaran memberikan peranan yang sangat pening dalam membantu proses pembelajaran, diantara peranan tersebut yaitu, siswa akan memiliki kemampuan menerima pembelajaran dengan baik, selanjutnya media pembelajaran membangkitkan motivasi siswa untuk belajar, memberikan pengaruh positif bagi pekembangan psikologis siswa, serta media pembelajaran mempunyai kemampuan dalam menampilkan berbagai kejadian, objek sesuai dengan keperluan dalam tujuan pembelajaran. Oleh sebab itu penggunaan media pembelajaran di kelas sudah merupakan suatu kebutuhan yang seharusnya di gunakan guru sebagai sumber belajar yang tidak dapat di kesampingkan lagi manfaatnya.

Penerapan e-modul sebagai media pembelajaran merupakan sesuatu yang dapat digunakan untuk menyampaikan pesan pembelajaran secara elektronik kepada peserta didik. Dimana media harus benar-benar membantu peserta didik untuk mencapai tujuan pembelajaran, memberikan rangsangan untuk memperhatikan pembelajaran, meningkatkan minat belajar, menguatkan pemikiran dan perasaan peserta terhadap meteri yang di terimanya melalui pemahaman materi yang disajikan.

Penggunaan e-modul juga memberikan efektifitas dalam pembelajaran, dimana kelebihan dari penggunaan e-modul untuk pendidikan yang dilakukan dengan jarak jauh atau daring, dilakukan secara interaktif, terstruktur, komunikatif, terdapat pengetahuan dan keterampilan di dalamnya.

\section{Metode Penelitian}

Pencarian data dilakukan dengan menggunakan search google scholar dan Sinta. Dengan kata kunci pembahasan "pengambangan e-modul pada mata pelajaran Simulasi Digital" dengan jumlah penelitian yang di review pada kategori sinta berjumlah 5 (lima) artikel dan di jabarkan dengan menggunakan metode analisis deskriptif. Sumber atau referensi yang diperoleh setelah dimetakan dan ditetapkan dengan kriteria inklusi.

\section{Hasil dan Pembahasan}

E-modul merupakan media pembelajaran berupa adaptasi dari komponen yang terdapat pada media pembelajaran dalam berbentuk cetak yaitu modul pada umumnya yang sering digunakan. Terdapat beberapa perbedaan anatara e-modul dan modul, perbedaanya yaitu dalam penyajian fisik. Untuk emodul sendiri disajikan menggunakan PC, Hp, menggunakan CD, USB, flasdisk atau sejenisnya, mudah untuk memperbanyak, naskah dapat dsusun secara linear maupun non linear. Sedangkan untuk modul cetak tentu saja tidak sepraktis pengunaan emodul. Dari segi penyajiannya modul berupa kumpulan kertas, sulit untuk dibawa kemana-mana, memakan biaya produksi.

Perkembangan teknologi informasi memung kinkan sesorang untuk dapat mengembangkan pembelajaran mengembangkan modul yang dalam bentuk cetak menjadi modul dalam bentuk elektronik atau lebih dikenal dengan (e-modul). Dengan tujuan agar pembelajaran lebih menyenangkan dan mudah dipahami oleh siswa agar dapat meningkatkan minat belajar dan hasil belajar yang baik. e-modul pada pelaksanaan sudah memenuhi uji kelayakan sebagai bahan ajar atau media yang mendukung terlaksananya kegiatan pembelajaran dengan maksimal, ini dibuktikan dengan hasil belajar siswa dalam kategori sangat baik dan juga sangat baik oleh ahli media. Hal ini membuktikan hasil belajar siswa dan respon siswa terhadap e-modul sudah mendapatkan hasil yang baik. Sehingga e-modul tersebut layak digunakan untuk membantu proses pemahaman materi bagi siswa dalam memahami materi pembelajaran.

Penelitian lain juga membuktikan bahwa pengembangan e-modul pada salah satu mata pelajaran di SMK yaitu pada mata pelajaran simulasi digital secara keseluruhan mendapatkan nilai persentase respon siswa sangat baik. Pembelajaran menggunakan e-modul mengajarkan pembelajaran secara mandiri kepada siswa, selain 
siswa dapat mengakses materi pada e-modul, siswa juga dapat mengakses tutorial dan vidio-vidio pendukung lainnya dalam memahami materi dalam waktu yang tidak terbatas, baik pada saat dalam jam sekolah maupun saat siswa sudah berada dirumah. Penggunaan e-modul berdampak pada hasil belajar siswa lebih baik, suasana yang menyenangkan bagi siswa akan menghasilkan pembelajaran lebih bermakna. Siswa lebih antusias terlibat aktif dari responden menunjukkan hasil yang sangat baik pada kategori e-modul layak digunakan sebagai media pembelajaran, namun pada salah satu penelitian menunjukkan ada kekurangan pada pengukuran hasil belajar atau disebut juga belum sampai pada hasil belajar.

E-modul sendiri sudah banyak dikembangkan dengan beberapa metode, dengan berbasis PBL, interaktif, proyek hingga berbasis android. Pengembangan yang dilakukan pada e-modul berbasis PBL khususnya pada mata pelajaran simulasi digital pada sebuah penelitian menunjukkan angka sebesar 90,6\% respon sisa yang artinya siswa merespon e-modul ini dengan sangat baik. Selain PBL hasil yang memuaskan ditunjukkan dengan pengembangan E-modul mata pelajaran simulasi digital pada materi blender memperoleh skor sebesar 3,07 yang termasuk katgori sangat baik. Kemudian pengembangan emodul berbasis proyek juga memperoleh hasil yang sangat baik dalam penggunaan e-modul yang berdampak positif terhadap hasil belajar siswa dan dinyatakan layak serta berhasil diterapkan. Sejalan dengan hal itu pengembangan e-modul berbasis aplikasi android dinyatakan efektif berdasarkan hasil yang diperoleh yaitu sebesar 83,33 menunjukkan kategori yang sangat baik.

E-modul memiliki kelebihan sebagai bahan ajar dibandingkan dengan bahan ajar beruba buku paket. Keuntugan e-modul terletak pada komunikasi dua arah yang dapat digunakan untuk pendidikan atau pelatihan jarak jauh, interaktif dan strukturnya lebih jelas. Selain dari hasil belajar siswa, respon siswa terhadap penggunaan e-modul juga memberi umpan balik yang baik. Melalui e-modul mampu meodorong guru agar guru mampu lebih kreatif dan inovatif dalam melakukan pengembangan media pembelajaran. penggunaan e-modul sendiri sangat sederhana dalam pengoperasiannya karena e-modul dirancang sesuai dengan jenis perangkat yang digunakan oleh siswa
Namun dalam penggunaan e-modul ini di SMK terkhusus pada mata pelajaran simulasi digital ditemukannya beberapa kekurangan dalam pelaksanaanya. Kekurangan yang sering ditemukan diantaranya yaitu akses jaringan yang belum merata, kendala dalam feedback secara langsung pada proses pembelajaran, sedikitya interaksi secara langsung antara peserta didik dan guru, tidak semua siswa dapat mengakses e-modul dikarenakan tidak semua siswa memiliki perangkat pendukung penggunaan e-modul. Penggunaan e-modul bagi siswa dengan minat baca atau belajar yang rendah akan menimbulkan kejenuhan dalam belajar.

Secara umum modul elektronika memberikan fasilitas kepada siswa untuk belajar secara mandiri agar siswa memperoleh pengetahuan melalui penggunaan materi presentasi, video animasi, dan penggunaan e-modul berdasarkan hasil uji. Hasil ini menunjukkan bahwa hasil dari penerapan e-modul diperoleh dengan menggunakan beberapa metode, desain dan implementasi dikembangkan dalam simulasi digital, berbasis proyek yang berhasil dan melalui implementasi dan evaluasi, pendekatan model PBL dan berbasis android.

Pengembangan e-modul secara digital dimaksud agar pembelajaran yang dilakukan bervariasi dan dapat meningkatkan literasi siswa dalam memahami memahami pembelajaran sehingga dapat mempermudah proses pembelajaran, dengan menggunakan e-modul siswa dapat belajar kapanpun dan dimanapun.

Kemajuan teknologi pada era sekarang menuntut guru untuk dapat memanfaatkan teknologi sebagai sarana memotivasi siswa dalam meningkatkan minat belajar secara efektif. Dengan kemajuan teknologi tersebut sangat disarankan kepada tenaga kependidikan untuk dapat secara efektif menggunakan teknologi sebagai alat bantu sumber belajar. Mengfungsikan media pembelajaran secara maksimal akan mempermudah guru atau pendidik dalam pelaksanaan pembelajaran, dan pada akhirnya akan menciptakan suasa belajar yang menyenangkan serta akan mendorong siswa untuk lebih giat dalam mencapai kompetensi.

Keberadaan e-modul juga merupakan solusi yang diberikan untuk memelihara kelestarian alam dan lingkungan, dengan adanya e-modul memberikan kontribusi positif pada pengurangan penggunaan kertas. Selain itu e-modul juga tidak dapat dikorosi oleh waktu, beda halnya dengan penggunaan buku cetak yang harus diproduksi pada 
saat buku tersebut sudah tidak layak digukan yang diakibatkan oleh perubahan bentuk fisik dan tulisan. Disisi lain penggunaan e-modul juga berdampak positif terhadap pembiaayaan yang akan dikeluarkan untuk membeli buku paket, e-modul dapat diakses secara gratis dengan menggunakan alat-alat bantu lainnya. E-modul juga dapat dibagikan dengan bebas tanpa pembiayaan yang harus dikeluarkan.

E-modul tidak hanya digunakan pada mata pelajaran simulasi digital saja, penerapan penggunaan e-modul juga banyak digunakan pada mata pelajaran adaptif dan produktif lainnya, seperti halnya di sekolah kejuruan penggunaan e-modul efektif diterapkan pada mata pelajaran produktif atau C3 dikarenakan pada mata pelajaran C3 menggunakan jobshet sebagai panduan pelaksanaan pembelajaran praktik, jobsheet dalam bentuk cetak bisa diadaptasikan kedalam bentuk e-modul, hal ini akan memudahkan siswa dalam memahami alur, langkah kerja, gambar rangkaian, serta simulasi pada saat praktek. Sama halnya seperti mata pelajaran adaptif kimia maupun fisika, dimana pada mata pelajaran ini siswa juga dituntut untuk bisa memiliki pengetahuan dan keterampilan didalam menerapkan kompetensi yang ada pada mata pelajaran tersebut.

Pada dasarnya e-modul adalah media yang sangat efektif dan cocok diterapkan pada semua mata pelajaran yang ada di Sekolah Menengah Kejuruan. Hal ini dikarenakan mampu meningkatkan kreatifitas peserta didik dan juga mampu meningkatkan kompetensi peserta didik. Namun pada kenyataan dilapangan tidak semua guru mampu mengembangkan media pembelajaran berbentuk e-modul. Dikarenakan masih banyak guru yang belum mengikuti perkembangan teknologi, serta masih banyak diantara guru yang masih belum mampu menguasai pembuatan e-modul dengan baik sesuai dengan kaidah-kaidah pembuatan modul dan Hal ini menjadi catatan dan tugas guru dalam meningkatkan kemampuan dan kompetensi dalam pemanfaatan media pembelajaran di era digital. Dengan meningkatkan kapasitas sumber daya manusia diyakini masalah kelemahan serta kesulitan dalam penyususan media pembelajaran yang efektif dan tepat guna akan menjadi solusi dari permasalahan pembuatan media pembelajaran yang efektif dan optimal penggunaanya

\section{Kesimpulan}

Implementasi e-modul pada SMK khususnya pada mata pelajaran simulasi digital memberikan impact positif selama pelaksanaannya. Dilihat dari hasil belajar siswa hingga respon siswa yang tinggi terhadap penggunaan e-modul. Secara keseluruhan e-modul bisa dinyatakan sangat layak untuk tetap digunakan. Beberapa jenis pengembangan yang digunakan untuk mengembangkan e-modul sudah membuktikan bahwa e-modul sangat efektif penggunaannya.

Penggunaan e-modul sebagai media pembelajaran dapat membantu guru dalam memberikan pembelajaran tanpa dibatasi oleh ruang kelas dan waktu dalam proses pembelajaran dan penggunaan e-modul juga memberikan kontribusi positif yang membatu siswa dalam memahami pembelajaran dengan baik, dikarenakan pada emodul terdapat beberapa fitur-fitur pendukung dalam mempelajari materi pembelajaran sesuai kompetensi yang diharapkan.

Kelebihan pada e-modul yaitu sangat efektif digunakan pada pembelajaran jarak jauh atau daring, keberadaan e-modul pada kondisi daring sangat membantu siswa dan guru dalam memperoloeh materi pembelajaran yang terstruktur dan sesuai dengan kompetensi yang diharapkan, meningkatkan literasi siswa, memotivasi, serta memberikan kemudahan bagi guru dalam proses pemberian dan penyampaian materi ajar.

Adapun untuk kekurangan penggunaan media emodul yaitu kekurangan perangkat yang disediakan dibeberapa sekolah untuk mengakses e-modul yang akan diterapkan.keterbatasan jumlah peserta didik yang belum memiliki secara individe perangkat yang akan digunakan untuk mengakses e-modul yang telah disediakan oleh pendidik.

\section{Daftar Rujukan}

[1] American Journal of Sociology. (2019). No Title No Title. Journal of Chemical Information and Modeling, 53(9), 1689-1699.

[2] I M. Suarsana, G.M. (2013). Pengembangan emodul Berorientasi Pemecahan Masalah, Jurnal Pendidikan Indonesia

[3] Sri, M., Dewi, A., Ayu, N., \& Lestari, P. (2020). E-Modul Interaktif Berbasis Proyek Terhadap Hasil. 4, 433-441.

[4] Tafanao, T. (2018). Peranan Media Pebeljaran dalam Meningkatkan Minat Belajar Mahasiswa. Jurnal Komunikasi Pendidikan.

[5] Wijayanti, N. P. A., Damayanthi, L. P. E., Sunarya, I. M. G., \& Putrama, I. M. (2016). Pengembangan E-Modul Berbasis Project Based Learning Pada Mata Pelajaran Simulasi Digital 
Untuk Siswa Kelas X Studi Kasus Di Smk Negeri 2 Singaraja. Jurnal Pendidikan Teknologi Dan Kejuruan, 13(2), 184-197.

[6] Winatha, K. R., Suharsono, N., \& Agustin, K. (2018). Pengembangan E-Modul Interaktif Berbasis Proyek Matematika. Jurnal Pendidikan Teknologi Dan Kejuruan, 4(2), 188-199.

[7] Yogyakarta, U. N. (n.d.). Pengembangan Electronic Module ( E-Module ) Pembelajaran Simulasi Digital Pada Materi Blender Untuk Siswa Kelas X Smk Negeri 1 Klaten. 1-10. 